\title{
Right to Food and Nutrition Watch 2017/10th Anniversary Issue
}

Published by a consortium of 26 civil society organizations and social movements and the Global Network for the Right to Food and Nutrition.

\section{By Claudio Schuftan, Ho Chi Minh City}

This review introduces the tenth anniversary issue of the Right to Food and Nutrition Watch, titled “The World Food Crisis: The Way Out” (which can be downloaded here in English, Spanish, French and Portuguese). It presents an alternative civil society perspective on the development of better food policy and better governance at local, national, regional and global levels. This year's peer-reviewed Watch takes stock of the decade since the 2007/2008 major world food crisis and examines challenges and opportunities that can be anticipated in the near future. It features ten thematic essays on pivotal issues and developments around the human right to adequate food and nutrition such as trade rules, climate change and emergencies, complemented by supportive national and regional reports from all regions of the world --from Haiti to Somaliland, Yemen and France to Nepal. Authors and contributors include academics, public interest civil society, peasant organizations and indigenous peoples’ leaders.

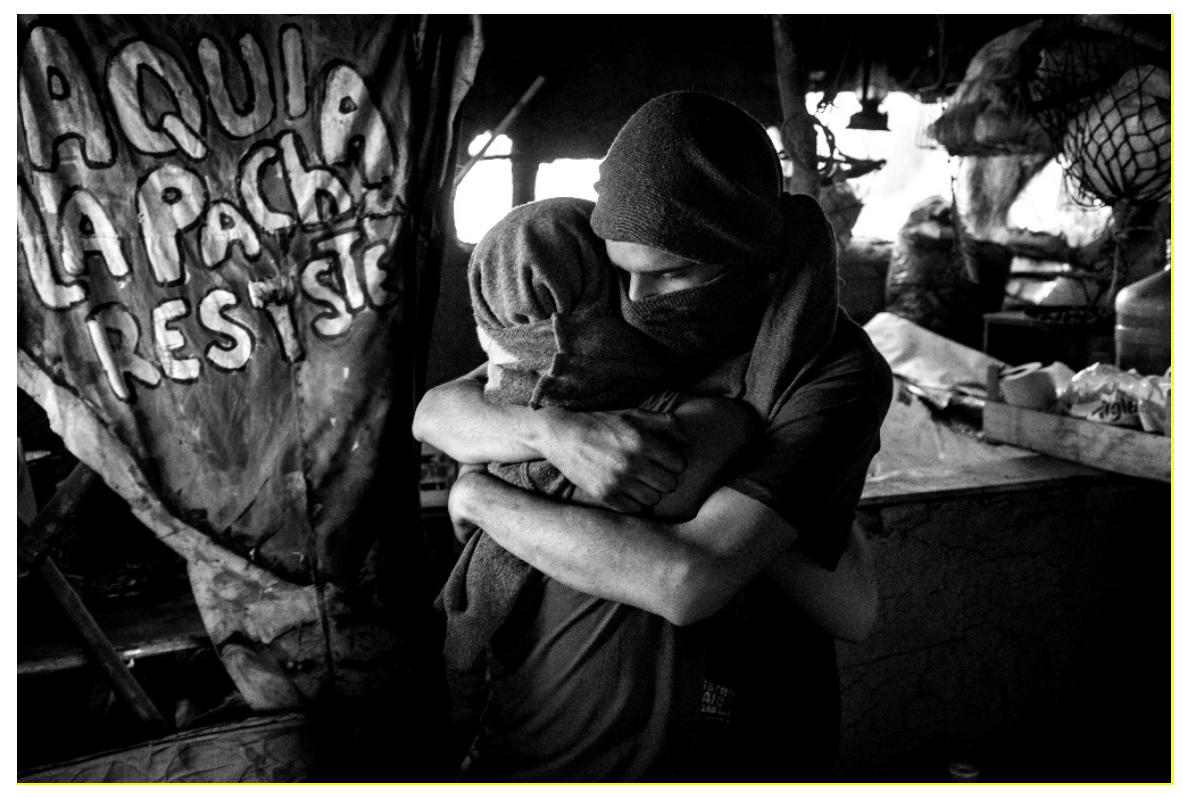

Photo by Pablo Ernesto Piovano. Activists resisting Monsanto (Córdoba, Argentina, 2015).

To give a flavor of the interesting information, insights, valid critiques and forward-looking proposals found in this must-read issue of the Watch, I distill just a few of its Pearls of Wisdom. 
The pursuit of the right to adequate food and nutrition is not a passive matter of progress in development, but rather a political struggle between opposing worldviews. Hunger, undernutrition and overweight do indeed have a history of serious policy failures. You will find plenty about this in the Watch. But you will also find that the right to adequate food and nutrition has been viewed and used through the manipulative lens of Social Corporate Responsibility --in their case, to unashamedly contribute to further profits. Corporations medicalize the challenges of nutrition and link solutions to changes they can make in the nutrient composition of foods and to technological changes in the prevailing agro-industrial food production system. We are witnessing a battle between the two main food system paradigms: food sovereignty vs the highly capitalized agricultural investment model. The paradox is that those that are mostly causing the problem are now asked (or volunteering) to design the solution(s)--and then actually end up benefitting from both the problems they cause and the solutions they propose.

Keep in mind: The global South moved from being a net agricultural exporter to becoming an importer around 1990 and, among them, the least developed countries' dependence has grown especially fast. We therefore ought to stop looking down at subsistence agriculture. In realty, agriculture is a way of life (or for life). We thus need to continue the struggle to preserve peasant agriculture and food systems that can really feed (and cool) the planet.

Add to this the fact that market oriented policies continue to reproduce gender inequality and, without questioning the sexual division of labor and fully organizing women's work and rights, there will be no progress for women. All human rights struggles are ultimately emancipatory projects based on people's social struggles.

Nobody dares to deny the importance of human rights to achieve a world free of hunger. And yet, something must be wrong, because year on year, decade after decade, particularly women continue to be marginalized and left by the wayside. Hunger wears the face of a peasant, but also of a woman. Yes, the struggle for human rights is anti-capitalist, but it must also be antipatriarchal, otherwise society will never be fair and just. Why? Because capitalism has an exclusionary approach; it excludes 'others'; instead it is self-centered and aims at maximizing profit centering around money-mediated market interactions. The global economy has become a casino where everything is speculated on and the interests of the financial sector override the needs of the people. The maxim “Accumulation by Dispossession” is fitting.

The plain truth is that the unfair rules set out at the World Trade Organization allow Europe, the US and other rich countries to continue with their agricultural subsidy regimes while severely restricting the policy and fiscal space available to African, Asian and other low-income countries to do the same. Solutions will have to emerge from experiences at the grassroots level and particularly from the growing political expertise and experience of increasingly active social movements. Activists in our field of public health nutrition must be informed and become much less compromising, i.e., must steer decisions towards what the real people-perceived problems are--at the same time recognizing the limitations of the system we live in.

Multi-stakeholderism, another problem denounced in the Watch, is spreading like a stain, we are told. The SUN initiative is given as an example. Being corporate-backed, SUN must be denounced. Why? Because, to begin with, there is little evidence that the SUN initiative is 
contributing substantially to increased public funding to combat under-nutrition; it is rather adding to the proliferation of global public-private partnerships in the area of food security and nutrition. Corporate partners within SUN, such as Mars or PepsiCo nicely create demand for their own products as they tap new markets with the blessing or even support of UN agencies. At the same time, these initiatives often support unsustainable magic bullet approaches, making low-income countries increasingly dependent on nutrients imported from wealthy country corporations.

Then, the Watch turns to the Decade of Action on Nutrition. We read that it cannot claim to be very optimistic, basically because it also sticks to multi-stakeholder solutions that are a false solution. The Decade contents--and so far, poor performance--blind us from the immensity of the issues at hand that go far beyond the field of nutrition.

The Watch has a warning for us: More of the same will lead to the demise of public policies and the death of what is left of their ethical content. But fortunately, we are told, human rights have been turned into an exploding moral discourse being used more and more. The latter notwithstanding, the pro-status-quo camp has been quick in turning human rights into a-moralobligation-of-charity, dependent on the goodwill of the few at the top. As a consequence, human rights are being depoliticized by the discourse of transnational corporations (TNCs) with the connivance of conflicted UN agencies and even states. Instead, we need human rights as an instrument of denunciation and resistance, simply because what is going on is, at its core, an ideological struggle. We thus need to politicize issues that have been perceived as technical or unchangeable. Human rights are not in crisis; they are an antidote to the crisis!

We must not forget: too often, human rights are being reduced to a mere quantitative transaction. Need proof? The Watch gives us one: most existing legislation on consumer rights recognizes that consumers are those that have exchanged money for a product, which means that those people who use other channels to access food such as bartering, soup kitchens, own production, or food aid do not enjoy any rights. Is this fair?

As regards natural resources, we are presented with another warning: it is wrong to assume that the depletion of natural resources is linear. Many ecological systems crash suddenly after they have hit some tipping point beyond which their natural reproductive capacity cannot function. (Think about the examples of over-fishing and the expansion of soybean farming for cattle feed into fragile soils, but there are many other).

The climate crisis also receives due attention in the Watch. We read that what we are in the midst of already is inextricably linked to the prevailing model of production, distribution and consumption, supported by a host of prevailing cultural values. Therefore, the climate crisis must be treated as a systemic crisis. Otherwise, the way things are, despoilers and polluters are winning; market mechanisms continue to be a way to sell rights to pollute and to extract; and there is a veritable impunity architecture around these planetary problems.

Not less of a problem is the fact that there is an inexplicable paralysis in public policies in relation to public access to land. It is local people who are the true guarantors of nature! The 
Watch thus recognizes the centrality of food as a commons, seen as a collective right, and consequently calls for collective governance over land.

Towards the end, the Watch makes an impassioned call for a transformation that simply must be systemic or it might, as well, not be undertaken at all. To start with, what is needed is to dismantle the architecture of impunity that TNCs and domestic elites enjoy, supported by free trade deals they often help to write. It is no news that, so far, TNCs are getting away with violating human rights. But things may take a turn. The UN Human Rights Council is currently debating a binding framework to hold TNCs to account.

How to counter the prevailing injustices in the food and nutrition sector is a question that has been philosophized throughout history. The very origin of human rights is deeply intertwined with historical, socio-political and economic clashes triggered by hunger, as well as food and nutrition shortages. Keep such historical facts in mind since the role of the struggle ahead is that of comprehending and fighting back (otherwise known as the radicalization of our struggle).

Download this issue of the Watch and find yet more valuable contents so relevant to all concerned with public health nutrition. 